\title{
Internationalisation in higher education for society - IHES in the times of corona
}

\author{
Uwe Brandenburg
}

\section{Contact}

Global Impact Institute s.r.o. Dělnicka 213/12

17000 Prague

$\triangle$ Correspondence: uwe.brandenburg@globalimpacti nstitute.eu

Copyright (C) 2020 by the author and publisher, TBU in Zlín.

This work is licensed under the Creative Commons Attribution International License (CC BY).

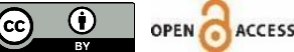

\begin{abstract}
Internationalisation has so far been largely disconnected from major societal developments such as the rise of xenophobia, climate change or more recently the Corona crisis and research on internationalisation for society is scarce. The article provides the definition of such internationalisation in higher education for society (IHES) as well as its characteristics developed in a mapping study for the German Academic Exchange Service and describes examples of IHES activities in universities around the world. The author shows, that IHES as a special form of Internationalisation at Home (laH) is still in its infant state, in contrast to classical internationalisation. The article then connects IHES with the most important societal challenge of our time: Corona, outlining different kinds of IHES activities that could be developed to help people during the Corona crisis. In a final excursion, the current movement towards online education as an answer to the Corona crisis is reflected upon from an IHES perspectives and possible applications are suggested.
\end{abstract}

Keywords: IHES, internationalisation, corona, society, impact

\section{Internacionalizace ve vyšším vzdělávání pro společnost - IHES v době koronaviru}

Abstrakt: Internacionalizace je zatím ve velké míře odpojena od zásadních aspektů společenského vývoje, jako je zvyšující se xenofobie, klimatické změny nebo v poslední době i krize okolo koronaviru. Výzkumy internacionalizace pro společnost se přitom provádí jen velmi zř́́dka. Tento článek poskytuje definici takovéto internacionalizace ve vyšším vzdělávání pro společnost (IHES) i její vlastnosti odhalené v mapovací studii pro Německé služby akademické výměny a popisuje př́klady aktivit IHES na univerzitách $v$ různých částech světa. Autor ukazuje, že IHES jako speciální forma domácí internacionalizace (Internationalisation at Home - laH) je $\checkmark$ porovnání $s$ klasickou internacionalizací stále ještě v plenkách. Článek spojuje IHES s nejvýznamnější společenskou výzvou naší doby - koronavirem - a načrtává různé druhy aktivit IHES, které by mohly být na pomoc lidem během koronavirové krize vyvinuty. $V$ závěrečném zhodnocení problematiky je provedena reflexe aktuálního posunu směrem k online vzdělávání jako odpovědi na koronavirovou krizi z perspektivy IHES a jsou navržena možná využití. 
Klíčová slova: IHES, internacionalizace, korona, společnost, dopad

\section{Why is internationalisation in higher education for society (IHES) relevant?}

The last decade has seen a substantial increase in various larger societal phenomena. Xenophobia and radicalisation have increased in the 20 years since the Durban Declaration in 2001 (United Nations, 2001), as the United Nations announced in 2016 (United Nations, 2016). At the same time, we see increasing anti-intellectualism (Gardner, 2016), while populism continues to raise its head all around the world (Roth, 2017). Beyond these social issues, we can observe the immense challenge to humanity and the entire planet in the form of climate change.

All of these and many more aspects are widely discussed in both academic and lay circles online and offline, with perspectives exchanged and actions taken. Interestingly though, the world of internationalisation in higher education has mainly abstained from engaging with these phenomena, especially during the last two decades. In the first mapping study for the German Academic Exchange Service (DAAD),Brandenburg, de Wit, Jones, Leask, and Drobner (2020) show that research on the idea of internationalisation in higher education for society (IHES) was practically non-existent, with very few exceptions including Brandenburg and Willcock (2019) and Streitwieser, Loo, Ohorodnik, and Jeong (2018). They also show that the identifiable initiatives were mainly individual and scarce, showing that IHES, in contrast to HE internationalisation as such, is still pretty much in its infant state. However, the study also indicates the immense potential of IHES in contributing to solutions of major social problems.

Most recently, the COVID-19 crisis, which started in January 2020 and reached truly pandemic status in February/March 2020, is an example for the relevance of IHES, with regard to both social responsibility and social engagement. Although no reliable data is available at the time of this article, it is statistically likely that international student, staff and conference mobility will have had its share in spreading the virus. Therefore, internationalisation carries a social responsibility for the consequences. On the other hand, the immense efforts in international joint research shows how internationalisation can also help to solve the crisis. And yet, so far there are very few initiatives in internationalisation engaging beyond the traditional target groups (students and staff).

This lack of focus on larger societal problems in internationalisation in higher education was raised for the first time by Brandenburg, de Wit, Jones, and Leask (2019a). They argue that in contrast to community outreach, social responsibility, social engagement and concepts such as service learning, which have been present in higher education around the world for decades, internationalisation activities have so far been mainly concerned with the higher education community itself, and the social responsibility aspect has remained largely neglected in terms of systemic thinking and conceptualisation. They further state that this is a severe imbalance which can no longer be ignored since higher education institutions (HEls) have - in the "Rousseauian" sense - a social contract with society and therefore bear some responsibility for it.

Based on widely accepted definitions of internationalisation (de Wit, Hunter, Rumbley, Howard, \& Egron-Pollak, 2015) and social engagement (Benneworth et al., 2018), they generate the term "internationalisation in higher education for society (IHES)" and define it as follows in a UWN blog:

Internationalisation in higher education for society (IHES) explicitly aims to benefit the wider community, at home or abroad, through international or intercultural education, research, service and engagement. 


\section{Why should HE internationalisation engage with society?}

There are various arguments for universities to engage with society through internationalisation in higher education. First and foremost, internationalisation is just one of the instruments universities apply, and it therefore has to also serve the three main foci of universities: education/teaching, research, and social engagement as the third mission. Second, universities have become increasingly involved in addressing the Sustainable Development Goals (SDGs) of the UN, e.g. through the University Social Responsibility Network (USRN) consisting of $16 \mathrm{HEls}$ from 11 countries (Chan, Hollister, liyoshi, \& Lloyd, 2020). Third, internationalisation generates substantial $\mathrm{CO}_{2}$ footprints: according to de Wit and Altbach (2020a), global student mobility produced $\mathrm{CO}_{2}$ equivalent to that of the entire countries of Croatia or Tunisia as early as 2014. In addition, the large international education conferences as well as numerous scientific conferences add considerably to this $\mathrm{CO}_{2}$ footprint of internationalisation. The University of California at Santa Barbara alone estimates that $33 \%$ of its carbon footprint was produced by air travel to international conferences and meetings (Levine et al., 2019).

In addition, IHES is becoming more important due to various developments in internationalisation, which the study outlines in detail:

1. From individual activities (late $80 \mathrm{~s}$ ) to systematic institutionalised comprehensive internationalisation.

2. From individual "nice-to-have" mobility experience to educating Global Citizens. ${ }^{1}$

3. The convergence of the concepts of internationalisation at home $(\mathrm{laH})$ and internationalisation of the curriculum (IoC).

4. From living on myths to fact-based accountability or ... from input to output, outcome and impact.

5. From Anglo-Western and European-centred internationalisation to a truly global approach and regional self-confidence.

(Brandenburg et al., 2020, pp.15-18)

\section{What precisely is IHES?}

IHES is closely connected to the realm of social engagement in HE. Brandenburg et al. (2020) extensively explored current research on social engagement and its definitions, with the main finding that, so far, social engagement is seen to be in competition with internationalisation for resources and priorities, rather than complementary to it (Benneworth et al., 2018). However, Brandenburg et al. (2020) conclusively argue that IHES is located precisely in the area of overlap between internationalisation and social engagement (see Figure 1).

1 The concept and definition of a "global citizen" is widely debated. Olds (2012) gives a good overview and provides five different perspectives: Global citizenship as a choice and a way of thinking, global citizenship as self-awareness and awareness of others, global citizenship as they practice cultural empathy, global citizenship as the cultivation of principled decision-making, and global citizenship as participation in the social and political life of one's community. 


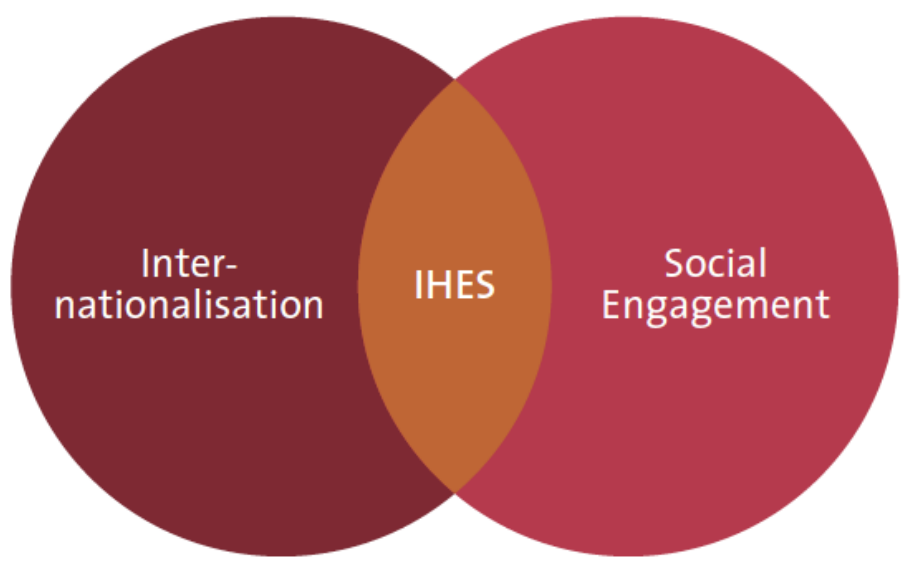

Figure 1 IHES located between internationalisation and social engagement

(Brandenburg et al., 2020, p. 19)

However, so far IHES is less developed than internationalisation. This can be best illustrated by applying the four stages of institutionalisation according to New Institutionalism (see Figure 2).

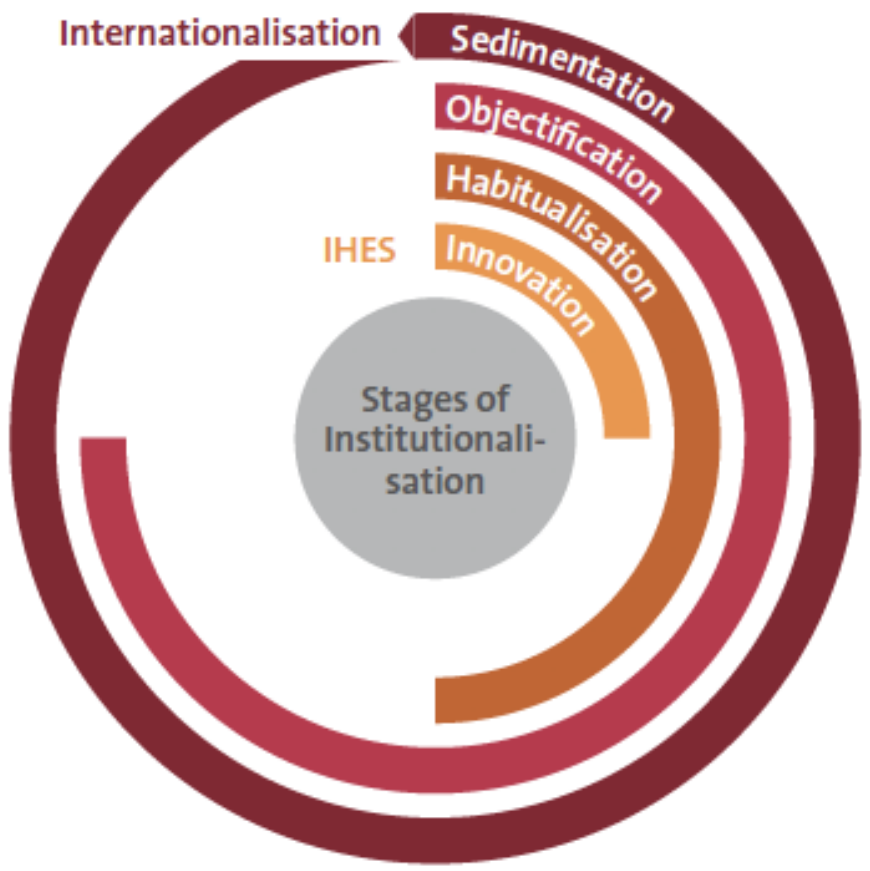

Figure 2 Comparing states of Institutionalisation between Internationalisation and IHES

(Brandenburg et al., 2020, p. 23)

In many parts of the world, internationalisation itself has already settled in the most advanced level of sedimentation; however, within regions and even countries we can also find differences between HEls regarding the state of internationalisation (for both, see Rumbley \& Sandström, 2019). On the other hand, IHES is everywhere still in the very first stage of innovation (Brandenburg et al., 2020). 


\section{$4 \quad$ What makes an internationalisation activity an IHES activity?}

The IHES definition as stated above implies three major characteristics of an IHES activity. First, it has to be explicit about its goal to benefit the wider public. This means that the target group of an IHES activity has to be, first and foremost, placed outside the university. In this way, unintended side effects of usual internationalisation, such as assumed influences on families and friends by returning exchange students or accidental interactions with local people during study abroad, are not considered IHES. This is one of the most important characteristics because it avoids the risk that every $\mathrm{HEI}$ claims to do IHES because "something for sure happens just by accident during normal internationalisation activities". IHES projects, in contrast, need to explicitly focus on a target group outside the HE community. By analysing 20 IHES examples from HEls and 6 from meta-level organisations (British Council and DAAD) - Brandenburg et al. (2020) developed the following list of such possible target groups (see Figure 3).

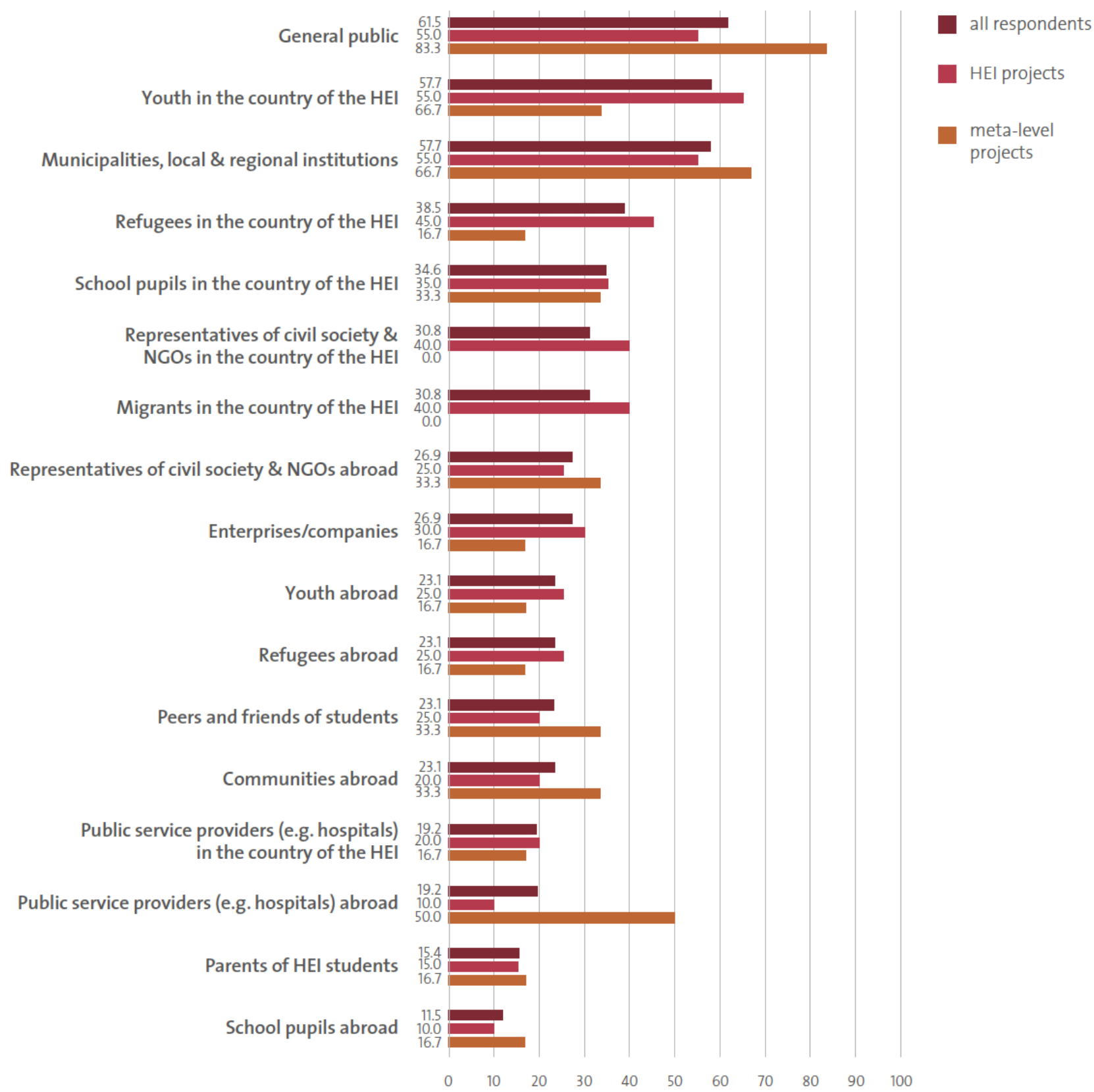

Figure 3 Share of projects including certain groups of actors

(Brandenburg et al., 2020, p. 54) 
The results are not necessarily what one would expect - even if we have to take into account that the study does not aim to be representative. The most dominant target groups found in the IHES projects were the general public, youth and municipalities, while refugees only came in at $4^{\text {th }}$ place and school pupils and parents seemed to be infrequently targeted.

The second characteristic is that IHES can happen at home, in the sense of internationalisation at home (laH), abroad, and also online; however, examples of online-based IHES have yet to be found, so far. The latter might play an increasing role in the future, not least due to the coronavirus crisis in 2020 (see below).

The third characteristic states that IHES projects can occur in any aspect of an HEl where internationalisation takes place: education, research, service and social engagement.

To precisely understand what an IHES project really is, what its characteristics are and how one can place one's own projects within the greater context, we can use the complex IHES matrix that Brandenburg et al. (2020) developed. Besides the already mentioned target groups, they identify 6 other IHES dimensions with different numbers of individual items and outline the frequencies with which those items appear in the 26 examples ( 20 from HEls and 6 on a meta-level). The first dimension is IHES goals (see Table 1), and they differentiate them into three major categories: public goods, economic development and social justice.

Table 1

IHES goals (Brandenburg et al., 2020, p. 43)

\begin{tabular}{ll}
\hline Public Good & Support social integration \\
& Support/preserve democracy \\
& Support/preserve peace \\
& Fight xenophobia/populism \\
& Fight radicalisation \\
& Support European identity \\
& Support the Sustainable Development Goals on the UN \\
& Develop global citizens \\
& Support the environment \& sustainability \\
Improve the acceptance of scientific results (instead of alternative facts) & and critical thinking \\
& Support science and knowledge diplomacy/soft power \\
& Provide practice oriented research \\
Economic Development & Support local/regional economy \\
Social Justice & Knowledge transfer \\
& General education of the public/capacity building \\
& Support active citizenship
\end{tabular}

The top 3 goals appearing in most projects were "General education of the public/capacity building," Support social integration" and "Develop global citizens."

The next dimension is the actor groups within the HEl. This seems to be a very crucial dimension since it moves students, for example, from their usual category of "beneficiary" or "recipient of a service" to that of an actor providing services to others. It contains 11 groups: leadership of the HEl; domestic and international academics and administrative staff employed by the $\mathrm{HEI}$; incoming international academics and administrative staff; domestic, international exchange and international degree students; and alumni (Brandenburg et al., 2020). Among these groups, the most prominent ones in the analysed examples were domestic administrative and academic staff, as well as international students. 
Next is the dimension of internationalisation, with the most comprehensive aspect being the following 19 items (see Figure 4).

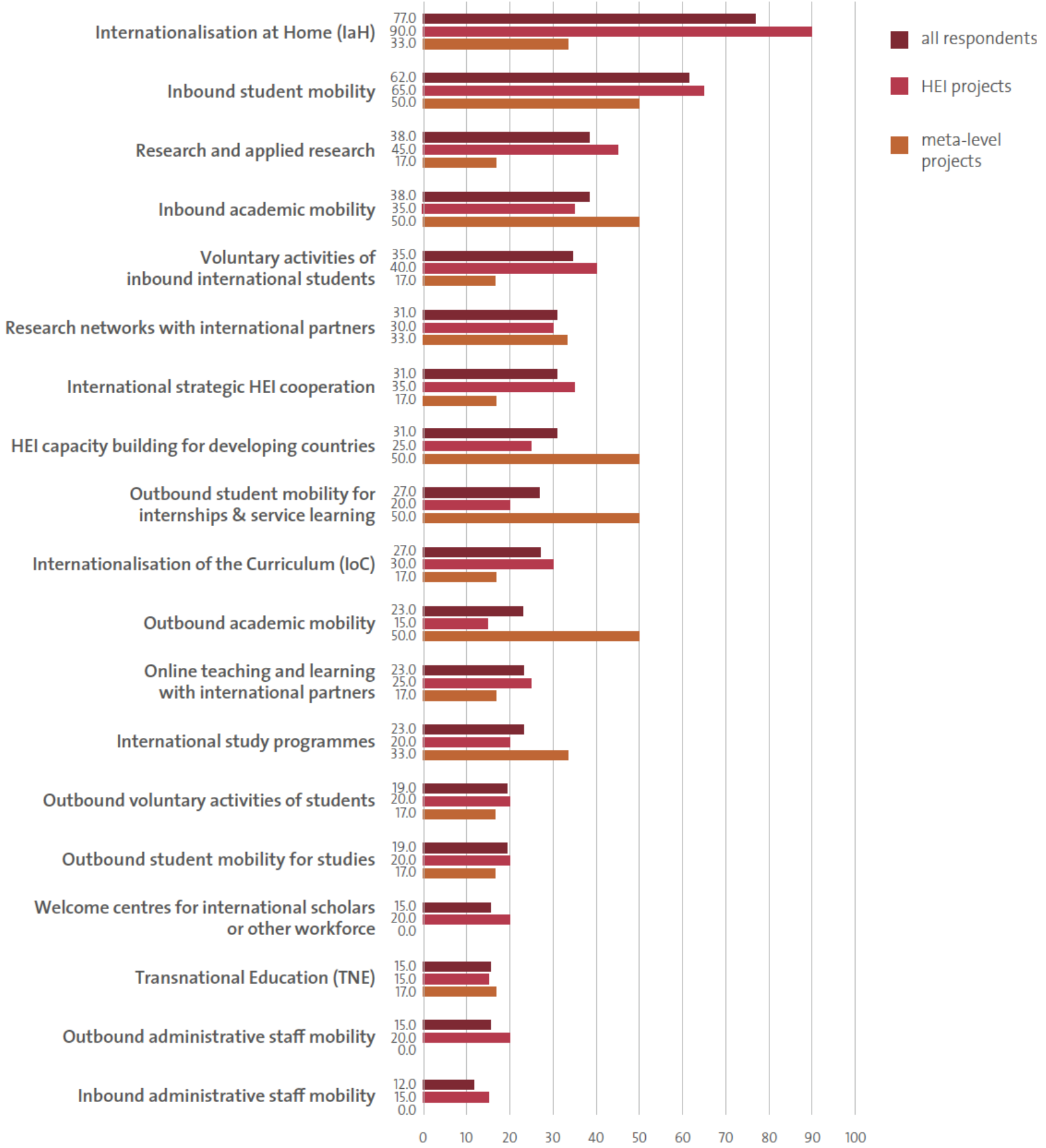

Figure 4 Share of projects incorporating certain dimensions of internationalisation (\%)

(Brandenburg et al., 2020, p. 55)

Two items show particular frequency: internationalisation at home (IaH) and inbound student mobility. The latter can be considered a precondition for the first. So indeed, IHES seems to be a perfect tool for laH, which can reach $90 \%$ of the non-mobile students, and considers them not only passive recipients but actors involved in the activity themselves, e.g. by matching them with returning mobile students or incoming international students in activities for the wider public. 
The other three dimensions have much more of a filter character, with few items. The involvement at the HEI differentiates between holistic (entire HEI), partial (only selected chairs / departments / units) and individual (single actors) involvement, and the analysis shows that in two-thirds of the cases, partial involvement can be observed. Movement between the HEl and society is an important dimension since it analyses whether the HEI moves into society to deliver IHES, or whether it brings society onto campus. Here we see a split, in that slightly more than $40 \%$ of the cases show both movements at the same time, while a similar percentage focuses on movements from the HEI into society. The last dimension asks for the prime beneficiary of an IHES activity. Since HEls cannot be assumed to act entirely altruistically, the question is whether the prime beneficiary shall be society or whether they pursue a "mutual benefit" approach. Not surprisingly, $88.5 \%$ of all projects pursue an approach of mutual benefit. This also seems wise, since it ensures a strong interest from the HEI as the actor in continuing its engagement.

\section{What is the scope of IHES projects?}

What the study mainly teaches us, in that part, is the enormous diversity of already existing projects, and consequently the vast opportunities that lie within the IHES concept. Brandenburg et al. (2020) group the $20 \mathrm{HEl}$ examples into five categories:

1. Refugee support projects.

2. IHES to support the regional economy.

3. IHES projects pursuing the goal of public goods in local communities.

4. IHES abroad.

5. IHES as a holistic concept.

These five categories are not necessarily all mutually exclusive, but it is striking that most of the identified projects fall into the category of laH (no.1-3 and also 5), while the holistic projects cover both mobility and laH. This will be highly relevant in the corona context later on.

Here, I want to outline one example per category to show the breadth and depth that IHES can take. Among the refugee projects the most outstanding seems to be Kiron University (headquarters in Berlin, two branch campuses in Beirut and Amman). It has been in existence since 2015 and has so far provided higher education for more than 6,000 refugees. According to the self-description provided for the DAAD study, Kiron is "not only supporting the fourth UN Sustainable Development Goal by enabling access to inclusive and quality education, its platform is continuously developing EdTech solutions for underserved communities" (Brandenburg et al., 2020, p. 58).

A striking example of an IHES project helping the local or regional economy is the Welcome Centre at the Georg-August University in Göttingen. The university already had a welcome centre for scientists for many years when regional industry approached the university with a problem: while the economy in the region was booming, it lacked a qualified workforce (Southern Lower Saxony is a relatively scarcely populated area). Attracting international workers was the only solution, but the industry faced two major problems: the region was not well-known, and the companies lacked the capacities and abilities to provide services to those workers to motivate them to come, and especially to stay, in the region. Since the university had established their welcome centre for very similar reasons, a joint venture was started, creating various welcome centres in the region built on the model and trained by the welcome centre of the university. The project was so successful that after a project funding phase, it is now working based on fees paid by the companies (Brandenburg et al., 2020, p. 61).

Relatively many projects could be detected that pursue the goal of providing public goods to local communities. Koç University in Turkey, for example, coordinates - in cooperation with Universidade 
Aberta (Portugal), University of Bologna (Italy), Erasmus University Rotterdam (Netherlands), Gaziantep University (Turkey) and Humboldt-Universität zu Berlin (Germany) - an Erasmus+ project called "Peacemakers". In their self-description they state that it "aims to foster a more peaceful generation in Europe and in Turkey that approaches migrants with positive attitudes. It will aim to achieve this objective by developing the problem-solving, critical-thinking and collaborative working skills of the participants through rigorous academic preparation, experiential education and leadership development. It aims to provide students with the education, training, and experiences needed to better understand, negotiate and resolve conflicts, in order to have more positive attitudes towards migrants. Skills, such as the students' ability to change their attitudes, will develop in this project, and are critical for their social life, workplace attitudes and all other mediums of exposure to people from diverse cultures. This project will enhance social, civic and intellectual competencies recognized as effective tools to prevent and tackle discrimination, radicalism, and racism. Core elements are boot camps and online courses, such as the train-the-trainers modules, in which students are taught to become trainers to teach both other students and non-HE audiences about the skills and knowledge needed to become peacemakers, so called 'Peace Envoys'"' (Brandenburg et al., 2020, p. 65).

IHES can also use the format of mobility, bringing a university's own students and/or staff to a community abroad, very much in the sense of service learning abroad. LaTrobe University, for example, has been running the Capacity Building Speech Pathology and Audiology project in Cambodia since 2015. It brings speech pathology and audiology students in their clinical placement phase to Cambodia, where they work closely with NGOs and provide both speech and hearing support services, especially to poor communities in rural areas. This project not only helps the local communities but, in my view, is also an excellent example of how IHES can benefit the actor groups (in this case the students from LaTrobe) by exposing them to communities in real need, and providing them with a perspective beyond the usually well-cushioned and low-risk, limited-problem society that they will later work in.

Holistic IHES concepts, as the final category, are still scarce, which is in line with the findings with regard to the innovation status of IHES itself. EARTH University in Costa Rica is one of the very few that takes IHES practically as the basis for its existence. It combines concepts of sustainability with wider participation and internationalisation in a completely immersed model. EARTH university integrates such concepts both in Costa Rica - bringing global expertise to the country - and in the home country of the graduates (the majority of students come from abroad, mainly from developing countries). As the self-description states: "Since its creation, EARTH has been an international university with students from underprivileged rural communities in developing countries, with an international faculty, an international internship program, and a global impact. EARTH's mission is to prepare ethical leaders, agents of change, who will contribute to sustainable development and construct a prosperous and just society. It is evident that this mission is relevant for people from all over the world. EARTH measures its success by the success of its graduates in improving the quality of life in their communities and countries. Improving the quality of life goes beyond economic justice and prosperity; it also means caring for the environment, and promoting constructive citizenship and positive values. EARTH also measures success by the impact of the outreach and research that it applies to solving the very real problems confronting the people in the communities and countries it serves. EARTH's dream is that its graduates, through their actions and EARTH's own activities in education, research and outreach, will play a significant role in bringing peace, helping to eradicate poverty, improving democracy, and creating a world that shares the universal values of honesty, respect and tolerance" (Brandenburg et al., 2020, p. 71). It seems hard to imagine a university with a strategic setup that provides a better full-scale IHES example than EARTH university.

There are also examples beyond this study: Kostrykina (in press) from the University of Auckland compares two approaches to IHES (New Zealand and Indonesia) to be presented at the IHES conference 2020 in Prague at the end of 2020. Drawing on case studies of internationalisation practice 
in New Zealand and Indonesia, she discusses the notions of social license and IHES. In the context of New Zealand, social licence involves resolving the challenges of pastoral care, student experience, and engaging the public with an internationalisation mind-set. The understanding of social licence in Indonesia is quite different. It is primarily based on the concepts of public goods, including benefitting the poor, community service, public dedication and public welfare, as well as addressing post-colonial issues. The notion of social licence is conceptualised in the context of the competing neoliberal and social development agendas, encouraged by governments and supported by the HEIS in New Zealand and Indonesia. Furthermore, Kostrykina (in press) outlines several mechanisms of constructing social licence as a part of the national internationalisation strategy, as well as their purposes and outcomes, and also locates the notion of social licence and the concept of IHES within a broader context of the global international education industry and the emerging global knowledge economy.

Another example of laH as a form of IHES are the welcoming weeks at the Poznan University of Medical Sciences and Poznan University of Technology. Foreign students are often welcomed at a university during orientation days/week. This is an opportunity to not only show students the campus and familiarize them with administrative procedures at the university, but also to immerse them in local culture and society, and get them acquainted with domestic customs and traditions. Polish universities use these weeks to interact with the local population, as a way to reduce xenophobic attitudes. This program helps "cushion" unpleasant situations, which contradict the self-image of the city of Poznan as an open city that welcomes everyone regardless of their race, nationality or religion.

\section{What is the relevance of IHES in a world of corona?}

When this special issue was planned, corona was only a distant problem in China. In the last few weeks it has become the defining aspect of life across the globe. This makes it a core IHES issue. So how does the corona crisis affect our idea of IHES, and what might IHES mean in the context of the crisis?

First of all, corona is a serious issue for internationalisation in general: logically, with international students and scholars having returned home and mobility made problematic for months, maybe a year, the practical concepts for IHES in terms of laH are severely limited, if we focus on real person engagement. However, domestic students, staff and scholars with international experience are still there and can, once quarantines and lockdowns have become a thing of the past, engage with the local community. In the times of corona, this is needed more than ever! Corona will support populist thinking, a herd mentality and ideas of separatism (similar to the US position in the first half of the $20^{\text {th }}$ century) - in short, "us vs. them". People will become even more concerned about "the other", and this is where IHES can play an important societal role by educating the general public. Brandenburg and Willcock (2019) have proven through an experimental design that this works.

I would like to outline three examples of possible IHES projects that would address the corona crisis:

a. IHES as a way to help deal with quarantine: this is already happening, as the Erasmus+ WILLIAM project on laH in Israel is right now developing tools and guidelines for parents and students around the globe, based on the knowledge and expertise of the Community Stress Prevention Centre and led by a professor of one of the WILLIAM partners, Tel Hai College. Materials are as we write this - being translated into various languages by European and Israeli experts, in order to share knowledge and, above all, to help parents (one of the target groups of IHES activities) feel safer and more competent in dealing with this situation. ${ }^{2}$ This kind of project addresses target groups such as the general public, pupils, parents, communities and municipalities. It could involve actor groups such as domestic and international students and staff and would mainly address the goal areas "public goods" and "social justice".

2 You can follow the developments on https://william-erasmus.com/category/coping-with-covid-19/ 
b. IHES to help stranded foreigners: hundreds of thousands of people are stranded abroad due to closing borders. Most do not have any contact persons and are not in higher education. Universities, however, now have experience with both getting people home and supporting those stranded on their campuses. This knowledge can be activated to help the non-HE foreigners. For this clearly defined IHES target group, different actor groups could be involved: domestic academics, students and not only administrative staff who might already have helped their international colleagues stranded on campus, as well as the international staff and students who have their own experiences to bring in. Again, the main goal areas would be "public goods" and "social justice".

c. IHES to fight corona-induced xenophobia: As Aguilera (2020) states, "xenophobia is a preexisting condition" which is further exacerbated due to corona. Xenophobia lives on fear of the unknown, and if people feel their life is in danger due to "foreigners" travelling, it spreads. IHES can help here by, for example, organizing online webinars and meetings in which people who are home alone, afraid and insecure, can meet with other people in other countries sharing the same fears. The actor groups in universities could be academics, students and administrators, who provide the platforms and also translate to their home communities what is being said on the other side.

\section{How can IHES be realized in a virtual world induced by corona?}

Corona is increasingly forcing universities into online education. de Wit and Altbach (2020b) started an interesting debate on COVID-19 and the consequences or lessons learned for internationalisation. However, they do not expect severe impacts because they assume that online mobility will remain a peripheral aspect, not yet ready to take over, mainly due to its still quite rudimentary technological state. Mobility will probably see a dip in the next 1-2 years but then return to normal, and that degree mobility will continue because of the sheer dependence on fee-paying students in many countries. While I would concur with the notion that the human being is mainly a creature of habit and has a short memory, so that things might get back to normal to some extent regarding mobility and especially degree mobility, I tend to disagree with regard to the impact of technology.

Many HEls had to literally move overnight to online teaching, counselling or lecturing. I am rather confident that corona will change internationalisation permanently with regard to virtual mobility and online education, a view supported by Politico in a fascinating article showcasing 34 eminent experts and their views on how corona will change the landscape (Politico Magazine, 2020). While many teachers will probably want to move back to classroom education as quickly as possible, many more will also discover the benefits of online education. Moreover, crisis creates innovation, and we can expect to see substantial improvements in the online environment: take the current debate on "zoombombing", for example, and the call for improvements in the security of online teaching environments (Redden, 2020). Therefore, I predict:

a. Tech solutions will see quantum leaps in quality over the next 12 months and beyond, moving fast in the direction of true virtual reality environments.

b. These solutions to laH will be much more acceptable to staff and students in the future since they have become used to it.

c. Due to the massive innovation in the field, the basic options will become more and more affordable. Even today, using platforms such as zoom produces costs that are a fraction of what needed to be invested only a few years ago.

d. While mobility will most likely need up to five years to get back to the status quo, as Simon Marginson estimates (Mitchell, 2020), HEls will redirect sum budgets towards laH and online mobility concepts. 
Building on this development, the next big step in internationalisation will be virtual reality (VR). Due to the extremely rapid technological development, especially in the area of VR environments, I expect within the next five years a quantum leap away from the currently slow, boring and not very engaging platforms (such as clumsy videochats, blackboards and shared folders) and opportunities towards a full-immersion concept, including true visual and haptic experiences with full-fledged avatars. If we just take the development in the gaming industry as the relevant indicator, VR environments will develop at a rate that we cannot even fathom at this stage. And then the implications for internationalisation will be huge. Once the artificial boundary between the human and the content (which at this point has to be accessed through a screen, and the interaction is keyboard-based) disappears, and the quality of imaging improves one to two levels, the difference between real and virtual reality will get blurred overnight. This will affect both mobility, for study and research, and conference participation, and it will also provide the first real opportunity to interest the $90 \%$ of students who are immobile to go abroad, albeit in a virtual way.

This development also produces an entirely new opportunity for IHES. Imagine IHES centres in which regular citizens in Spain or Portugal can go into a virtual room, are transported beyond any border towards China or Korea, and are immersed in a concrete, haptic, acoustic and visual experience in a different country that can open their mind? Or that nurses in Bangladesh or Germany can enter such a room, find themselves in a teaching hospital in Stockholm or Mombasa, interact with their colleagues, and improve their knowledge? All this can happen without extra expenses, without any relevant $\mathrm{CO}_{2}$ footprint (virtual mobility is not a zero- $\mathrm{CO}_{2}$ activity!) and without having to arrange for family or work responsibilities. In this way, VR-IHES can achieve three major goals:

- Successfully address the problem of climate change by substantially reducing the $\mathrm{CO}_{2}$ footprint of internationalisation.

- Move far beyond the classical minority of individuals benefitting thus far from internationalisation in two categories, by engaging the $90 \%$ of the non-mobile students and, among those, especially the economically disadvantaged, in the sense of true widening participation.

- Involve a much larger proportion of local non-HE target groups (such as the general public, pupils and parents) in an even more impactful way by transporting them into a new environment without risks and costs.

And who knows: maybe such virtual experiences will then also motivate more people to take up studies, and more students to finally go abroad in a real mobility.

As always, a crisis can also be a huge opportunity, and change usually only happens under external pressure.

\section{References}

Aguilera, J. (2020). Harmful stereotypes and racism are spreading around the Coronavirus. Retrieved from https://time.com/5775716/xenophobia-racism-stereotypes-coronavirus

Benneworth, P., Ćulum, B., Farnell, T., Kaiser, F., Seeber, M., Šćukanec, N., Vossensteyn, H., \& Westerheijden, D. (2018). Mapping and critical synthesis of current state-of-the-art on community engagement in higher education. Retrieved from https://research.utwente.nl/en/publications/mapping-and-critical-synthesis-of-current-stateof-the-art-on-com.

Brandenburg, U., de Wit, H., Jones, E., \& Leask, B. (2019b). Defining internationalisation in HE for society. 
Brandenburg, U., de Wit, H., Jones, E., \& Leask, B. (2019a). Internationalisation in higher education for society. Retrieved from https://www.universityworldnews.com/post.php?story=20190414195843914

Brandenburg, U., de Wit, H., Jones, E., Leask, B., \& Drobner, A. (2020). Internationalisation in higher education for society (IHES). Concept, current research and examples of good practice (DAAD Studies). DAAD. Retrieved from https://www2.daad.de/medien/DAAD-aktuell/ihes_studie.pdf

Brandenburg, U., \& Willcock, B. (2019). The impact of an international component in educating the public using an experimental design. Journal of Studies in International Education, advance online publication. https://doi.org/10.1177/1028315319889892

Chan, S., Hollister, R., liyoshi, T., \& Lloyd, A. (2020). University social responsibility movement gains traction. $\quad$ Retrieved from https://www.universityworldnews.com/post.php?story=20200323131413245

de Wit, H., \& Altbach, P. (2020a). Time to cut international education's carbon footprint. Retrieved from https://www.universityworldnews.com/post.php?story=20200108084344396

de Wit, H., \& Altbach, P. (2020b). COVID-19: The internationalisation revolution that isn't. Retrieved from https://www.universityworldnews.com/post.php?story=20200312143728370

de Wit, H., Hunter, F., Rumbley, L., Howard, L., \& Egron-Pollak, E. (2015). Internationalisation of higher education. study requested by the european parliament. European Commission. Retrieved from https://www.europarl.europa.eu/RegData/etudes/STUD/2015/540370/IPOL_STU\%282015\%2 9540370_EN.pdf

Gardner, A. (2016). The rise of anti-intellectualism and its repercussions for society. Retrieved from https://www.inquisitr.com/2917549/the-rise-of-anti-intellectualism-and-its-repercussionsfor-society/

Kostrykina, S. (in press). Never the twain shall meet? IHES in New Zealand and Indonesia. IHES Conference.

Levine, C., Miller, E., Morgan, B., Taylor, J., Voskuil, L., Williams, D., Kreisel, D., Roop, H., Wheeler, S., Bloom, A., Howarth, R., Atkinson, D., \& Albritton Jonsson, F. (2019). Reducing the carbon footprint of academic travel. Retrieved from https://www.insidehighered.com/views/2019/04/18/12-scholars-share-ideas-reducingcarbon-emissions-academic-travel-opinion

Mitchell, N. (2020). Five years to recover global mobility, says IHE expert. University Retrieved from https://www.universityworldnews.com/post.php?story=20200326180104407

Olds, K. (2012). Global citizenship - What Are we talking about and why does it matter? Retrieved from https://www.insidehighered.com/blogs/globalhighered/global-citizenship-\%E2\%80\%93what-are-we-talking-about-and-why-does-it-matter.

Politico Magazine. (2020, March 19). Coronavirus will change the world permanently. Here's how. Retrieved from https://www.politico.com/news/magazine/2020/03/19/coronavirus-effecteconomy-life-society-analysis-covid-135579\#tech

Redden, E. (2020). 'Zoombombing' attacks disrupt classes. Retrieved from https://www.insidehighered.com/news/2020/03/26/zoombombers-disrupt-online-classesracist-pornographic-content

Roth, K. (2017). The dangerous rise of populism. Global attacks on human rights values. Retrieved from https://www.hrw.org/world-report/2017/country-chapters/dangerous-rise-of-populism 
Rumbley, L., \& Sandström, A. (2019). EAIE Barometer (second edition): Money matters. Retrieved from https://www.eaie.org/our-resources/library/publication/Research-and-trends/eaiebarometer-money-matters.html

Streitwieser, B., Loo, B., Ohorodnik, M., \& Jeong, J. (2018). Access for refugees into higher education: A review of interventions in North America and Europe. Journal of Studies in International Education, 23(4), 473-496. https://doi.org/10.1177/1028315318813201

United Nations. (2001). World Conference against Racism, racial discrimination, xenophobia and related intolerance. Declaration. Retrieved from https://www.un.org/WCAR/durban.pdf

United Nations. (2016). Racism, xenophobia increasing globally, experts tell third committee, amid calls for laws to combat hate speech, concerns over freedom of expression. Retrieved from https://www.un.org/press/en/2016/gashc4182.doc.htm

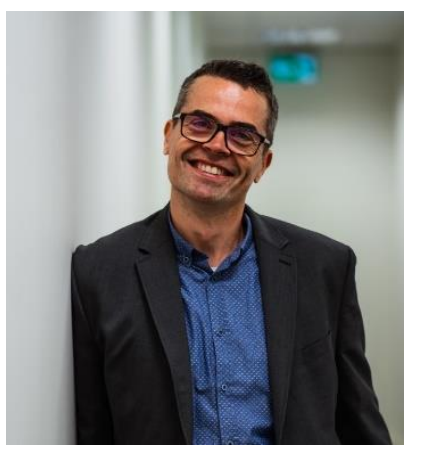

Uwe Brandenburg holds a PhD from the University of Bristol in Globalisation Studies, an MscEcon from the University of Wales at Swansea and an M.A. in Islamic Sciences from the WWU Münster. He is currently the Managing Director of the Global Impact Institute in Prague and Associate Professor for Regional Cooperation and Impact of Higher Education at the University Rovira I Virgili in Tarragona, Spain. Prior to that he was Managing Partner of CHE Consult and CHE Consult Prague. He was also Director International at the Humboldt-Universität zu Berlin for eight years. Uwe has published widely on the topic of internationalization such as the much debated article with Hans de Wit on the end of internationalization in 2011 in the Boston IHE. He was the head author and team leader for both the Erasmus Impact Study (EIS, 2014) and the followup EIS Regional Analysis (EIS RA, 2016), the European Voluntary Service Impact Study (2017). He frequently presents on international conferences around the globe. He also frequently coaches individuals in leadership positions, teaches at different universities and conducts research. Uwe currently focuses his work on impact and Internationalisation in Higher Education for Society (IHES). Uwe gave a TEDx talk on the Magic of Change in March 2019 which is also on his youtube channel. Uwe is a fervent believer in the value of change based on his personal experience as well as professional and academic insights. His research interests are internationalisation for society, the influence of technological developments on internationalisation and the assessment of impact. 